\section{Prof. Johan van Baren}

BY the death on February 7 of Prof. Johan van Baren, agricultural science has lost the leading authority on soil mineralogy. Born in Rotterdam on April 18, 1875, van Baren became assistant in mineralogy to Prof. J. L. C. Schroeder van der Kolk, of the University of Delft, in 1899. In 1903 he went to Wageningen, where he taught mineralogy and geology at the Agricultural College, and when this College was made an Agricultural University, in 1918, he was appointed professor of mineralogy, geology and agro-geology.

When van Baren went to Wageningen, his facilities for teaching and research were of the most meagre kind, but in the thirty years he spent there he built up a department for his subject which at the present time has no equal. The museum and library, to which he devoted much attention, are particularly fine.

Besides his University work, van Baren had interests in many societies. He was one of the founders of the Geological Society of the Netherlands and Colonies, of the Society for Studying the History of Mathematical and Physical Science, and of the Wageningen section of the Dutch Natural History Society. He was for many years on the Committee of the Royal Dutch Geographical Society, and was a corresponding member of the French Academy of Agriculture. In the International Society of Soil Science he was an active member. He contributed papers to various conferences of the Society and took part in the preparation of the Soil Map of Europe. He devoted much attention to the soils of the East Indian Archipelago, and raised the Junghuhn Fund for the study of these soils.

Van Baren's principal work was a handbook, "The Soil of the Netherlands", in the preparation of which he was occupied for more than twenty years: altogether he published more than a hundred scientific papers. He was particularly interested in the Quaternary deposits of Holland and their correlation with the glacial phenomena of the Alps and Scandinavia. He also studied recent volcanic deposits of the East Indian Archipelago. In soil work he specialised in detailed mineralogical studies, and published a series of memoirs treating of the soils of Holland and the East Indian Archipelago (issued from the Geological Institute of the University of Wageningen). More recently he devoted particular attention to the problems of origin and development of limestone soils under the very contrasting climatic conditions of tropical and temperate regions. In pursuance of his studies he travelled extensively both in Europe and the East.

Van Baren was an inspiring teacher. The writer has vivid and pleasant recollections of an excursion to South Limburg with him and his students in the early summer of 1926-busy days spent in field work, meals taken together at one long table in the hotel at Valkenburg, and discussions and amusements in the evenings. The best of good fellowship existed and when the day's work was done, van Baren joined in the students' concerts with the same enthusiasm as he showed in leading the excursions. A vigorous man of kindly per. sonality, he will be greatly missed by his friends and colleagues in soil science in other countries as well as Holland.

W. G. O.

\section{Mr. F. P. Burch}

WE regret to announce the death on February 11 at the age of thirty-three years of Mr. Francis Parry Burch. He was the second son of the late Prof. G. J. Burch, F.R.S., of University College, Reading, and was a scholar of Winchester and of Gonville and Caius College, Cambridge, where he took the Natural Science Tripos, Part II (Physics) in 1922 .

Burch joined the staff of the Research Department of the Metropolitan-Vickers Electrical Co., Ltd., Manchester, in 1922 as a member of the newly-formed Physics Section, devoting much of his time to the problems of heat transmission, and in the early days of the radio industry he made a careful study of the characteristics of filaments for receiving and transmitting valves. With the development of apparatus for producing electrical transients of extremely short duration, it became necessary to extend the existing facilities for recording these transients, and in conjunction with Mr. R. V. Whelpton he constructed the first high-voltage cathode ray oscillograph in Great Britain. To put the recording of high voltage transients on a sound basis, Burch made a careful study of the theory of the potential divider, completing this valuable work by constructing an apparatus to record transients up to one million volts.

Burch then turned his attention to the continuously evacuated power transmitting valve and rectifier, and was largely responsible for the successful completion of a $30 \mathrm{kw}$. screened grid valve and master oscillator operating at a wavelength of $10 \mathrm{~m}$., the first high power four-electrode valve in the world.

By his death the Metropolitan-Vickers Co. has suffered a great loss, and is robbed of one of its most charming personalities.

WE regret to announce the following deaths :

Dr. John Belling, cytologist in the Department of Genetics of the Carnegie Institution of Washington, an authority on the structure of chromosomes, on February 28, aged sixty-six years.

Prof. G. C. Bourne, F.R.S., emeritus professor of zoology and comparative anatomy in the University of Oxford, who did much work on tropical marine fauna, especially on the formation of coral atolls, author of a "Text-Book of Oarsmanship" published in 1925, on March 9, aged seventy-one years.

Dr. R. T. A. Innes, formerly Union Astronomer in South Africa, known for his discoveries and records of binary stars, on March 13, aged seventyone years. 